\title{
IDENTIFICATION OF ASPERGILLUS SP MUSHROOMS IN WHEAT FLOUR SOLD OPENLY IN CIROYOM MARKET AS RAW MATERIALS FOR HALAL AND MUNGLE-FREE
}

\author{
Fitri Rahmi Fadhilah ${ }^{1}$, Ally Kafesa ${ }^{2}$, Sopi Napita ${ }^{3}$ \\ Institut Kesehatan Rajawali Bandung \\ Correspondence Author: ffitrirahmi@gmail.com
}

\begin{abstract}
Wheat flour is used as the main ingredient of food which is often used by the wider community, one of which is as an ingredient for making various kinds of food products. Wheat flour is included in food products safe and halal for consumption. The wheat flour which is sold openly is packaged in transparent plastic. With the easy-to-open packaging, it is easy for microorganisms to enter the flour, one of them is fungus. This study was aim to determine the types of Aspergillus sp in wheat flour which is sold openly in the Ciroyom Market. Method The research used is descriptive by using 30 samples of wheat flour which are sold openly in the Ciroyom Market. This research was conducted in the laboratory of the Rajawali Health Institute, Bandung. Result and Discussion: The results of this study showed the presence of Aspergillus flavus (50\%), Aspergillus fumigatus (50\%), Aspergillus niger (16.7\%), Aspergillus terreus (3.3\%) and negative (26.7\%) Aspergillus sp. Conclusion: From this research, it can be concluded that the species of Aspergillus flavus, Aspergillus fumigatus, Aspergillus niger and Aspergillus terreus were found so we can conclude that the wheat flour that is sold openly is still a halal product but it is not mushroom-free products.
\end{abstract}

Keyword: Wheat flour, Aspergillus sp, Sold Openly, Ciroyom Market.

Abstrak: Tepung terigu dijadikan sebagai bahan utama makanan yang sering digunakan masyarakat luas salah satunya sebagai bahan pembuat aneka olahan atau berbagai macam produk makanan. Tepung terigu termasuk ke dalam produk makanan aman dan halal untuk dikonsumsi. Adapun tepung terigu yang dijual secara terbuka dikemas oleh plastik transparan sehingga dengan kemasan yang mudah terbuka mengakibatkan mikroorganisme mudah masuk kedalam tepung salah satunya jamur. Tujuan Penelitian ini untuk mengetahui adanya jenis-jenis Aspergillus sp pada tepung terigu yang dijual terbuka di pasar ciroyom. Metode penelitian yang digunakan adalah deskriptif. Dengan menggunakan 30 sampel tepung terigu yang dijual secara terbuka dipasar ciroyom. Penelitian ini dilakukan dilaboratorium Institut Kesehatan Rajawali Bandung. Hasil dari penelitian ini menunjukan adanya Aspergillus flavus (50\%), Aspergillus fumigatus (50\%), Aspergillus niger (16,7\%), Aspergillus terreus $(3,3 \%)$ dan negatif (26,7\%) Aspergillus sp. Kesimpulan: Dari penelitian ini dapat disimpulkan bahwa, ditemukannya jenis Aspergillus flavus, Aspergillus fumigatus, Aspergillus niger dan Aspergillus terreus sehingga dapat disimpulkan bahwa tepung terigu yang dijual secara terbuka masih merupakan produk halal tetapi bukan produk bebas jamur.

Kata Kunci: Tepung Terigu Aspergillus sp, Dijual Secara Terbuka, Pasar Ciroyom. 
INTRODUCTION

Wheat flour is the main raw material used in the manufacture of various food products, such as: (bakery), noodles (noodles), spaghetti, pizza, etc. Wheat flour is rich in carbohydrates, but very little in vitamins and minerals. To enrich the nutrient content, several food additives are often added as a fortification of wheat flour.

Decree of the Minister of Health Rep. Indonesia No. 962/Menkes/SK/VII/2003 concerning Wheat Flour Fortification states that flour produced, imported or circulated in Indonesia must contain fortifications, which include: iron (Fe), zinc ( $\mathrm{Zn})$, vitamin B1, vitamin B2, and folic acid.

In terms of halal, wheat flour is relatively no problem. However, various added ingredients and improving agents are susceptible to various contaminations of illicit substances. For example, vitamin B1 (thiamine), vitamin B2 (riboflavin), and folic acid (folic acid) which are sourced from halal plants are consumed. These vitamins change status to non-halal when they are produced microbiologically using non-halal media.

The selection of wheat flour is also very important as a food raw material that is safe for consumption. Like low protein wheat flour, it is wheat flour that is commonly used to make cookies, cakes, pastries and fried foods. So that the texture of the cuisine becomes more crunchy. The protein composition contained in wheat flour is about $8 \%$ to $11 \%$. This flour is also durable and not easily moldy while so far there are some wheat flours that are sold without packaging, especially if they are stored openly like in traditional markets

According to $\mathrm{WHO}$, there are more than $50 \%$ of diarrheal diseases caused by contaminated food, causing 550 million people to experience illness and death as many as 230,000 people (WHO, 2015). Meanwhile, according to BPOM, food poisoning in Indonesia in 2014 was 974 cases and decreased to 697 cases in the following year. In 2016 food poisoning again increased to 791 cases and the morbidity rate due to food poisoning was the highest case (BPOM, 2017). One of the causes of poisoning is Aspergillus sp.

Aspergillosis is a disease caused by the fungus Aspergillus. Aspergillus sp is a eukaryotic microorganism that has the widest distribution area and is abundant in nature, often found in various habitats, but generally saprophytes in the soil. Aspergillus sp. has a very small and light spore size so that it is easily spread by the wind (Utami et al., 2012). Room temperature conditions of $20-25^{\circ} \mathrm{C}$ as well as organic materials such as carbohydrates, proteins, and fats are needed by Aspergillus to grow and reproduce. In addition, aspergillus is able to live on materials that have a high degree of acidity and starch content (Alvarez et al, 2010).

Aspergillus sp has species namely Aspergillus niger, Aspergillus flavus, Aspergillus fumingatus, and Aspergillus terreus. In addition, this fungus can produce mycotoxins, which are called aflatoxins. Mycotoxins are part of secondary metabolites in fungi that can contaminate food and cause poisoning in humans. If a person consumes food contaminated with Aspergillus sp. continuously for a long period of time, it will cause diseases such as liver cancer, central nervous system disorders, leaver and hepatitis (Andoro A, 2011). 
Wheat flour is used as the main ingredient of food which is often used by the wider community, one of which is as an ingredient for making various processed or various kinds of food products. Wheat flour comes from wheat seeds that are finely ground into flour. The wheat seed used to process flour is only the inner part called the wheat endosperm (Separinta, 2017). The content contained in flour is $8 \%$ protein content, $12 \%$ water content, $1.3 \%$ ash content, $1.5 \%$ fat, $2.5 \%$ fiber, and starch with a range of 60-68\% (Sunarsi, et al 2011).

Ciroyom Market is one of the biggest markets in the city of Bandung, located right at the Ciroyom terminal, there are several stalls and shops as a place to sell. Ciroyom market is listed as one of the largest waste-producing places in Bandung city, so that garbage builds up in temporary dumps. The condition of the market is muddy, there is a chicken slaughter place not far from the trade where the rinse water of the slaughtered chicken does not go directly to the water disposal but is scattered into the streets, and there is garbage that is dumped near the store so that it can trigger the growth of fungi where the spores can be carried away by the wind (Nano, 2018).

The wheat flour which is sold openly is packaged in transparent plastic. Coupled with the easy-to-open packaging, it is easy for microorganisms to enter the flour, one of which is fungus. Factors that can affect the occurrence of contamination in wheat flour are packaging factors, environmental factors, and storage duration factors (Pudatiati, 2018). One level of damage during storage is air circulation in storage, the humidity of the storage room temperature is $25-27{ }^{\circ} \mathrm{C}$. The presence of microorganisms that grow in a food ingredient greatly affects the quality of the product (Mizana D, 2016).

According to research conducted by Wiwik Pujiati in 2018 with the topic of Aspergillus sp. on wheat flour which is sold openly in the Legi Jombang market, the results obtained were 71.40\% Aspergillus niger, Aspergillus flavus and Aspergillus fumigatus obtained $14.30 \%$ with the same percentage. According to research conducted by repertoire in 2013 with the topic of the effect of storage time on the diversity of mold contaminants in wheat flour, it was found that the presence of Aspergillus sp, Penicillium funiculosum, Eupenicillium hirayamae, Cladosporium sphaerospermum, and Rhizopus. To identify Aspergillus sp, namely macroscopically and microscopically. Based on the description above, the authors are interested in conducting an examination of "Identification of the fungus Aspergillus sp in wheat flour which is sold openly in the Ciroyom Market".

\section{METHOD}

\section{A. Tools Sterilization}

1. The tools to be used are prepared in advance.

2. The tool is washed and dried

3. The tool is put into an autoclave with a temperature of $121^{\circ} \mathrm{C}$ (Murniana, 2011).

\section{B. Making SDA Media (Sabourand dextrose agar)}

1. SDA media was weighed as much as 40.3 grams. using a digital scale and inserted into the Erlemeyer. 
2. Add $620 \mathrm{ml}$ of distilled water into the Erlenmeyer.

3. SDA media is heated above the spirit with a tripod.

4. The media is homogenized with a stirring rod until it boils.

5. Erlenmeyer is closed with a cotton plug.

6. The medium was sterilized using an autoclave at $121^{\circ} \mathrm{C}$.

7. The medium is allowed to stand until it becomes solid.

\section{Isolation of Fungi on SDA (Sabouraud Dextrose Agar) Media Using the Seedling (Sow) Method}

1. The sample is first weighed as much as 1 gram, then fix the periphery of the petri dish by passing it in the spirit, open the petri dish and then sprinkle the flour on top of the media that has been solid until smooth.

2. Fixation of the petri dish that has been planted with wheat flour samples and then incubated for 3-5 days at a temperature of $27 \mathrm{C}$

3. Observations were made macroscopic by looking at the color of the colony, the shape of the colony on the media.

\section{Microscopic examination}

1. The tools to be used are prepared in advance.

2. A few drops of distilled water are placed on the object glass.

3. The ossicles are fixed above the spirtus.

4. Colonies are taken and then placed on a glass object that has been given distilled water and mixed.

5. LPCB (Lactophenol cotton blue) was dripped as much as $50 \mathrm{~m}$ and covered using a glass deck.

6. Observed under a microscope with a magnification of $40 \mathrm{x}$

\section{RESULT AND DISCUSSION}

This research was conducted at the Microbiology Laboratory of the Rajawali Health Institute, Bandung in June 2021. This research began with sampling at the Ciroyom market and inoculation, then continued with the identification of Aspergillus in wheat flour that was sold openly.

\subsection{Identification Results of Aspergillus in Wheat Flour Sold Commercially Open at Ciroyom Market}

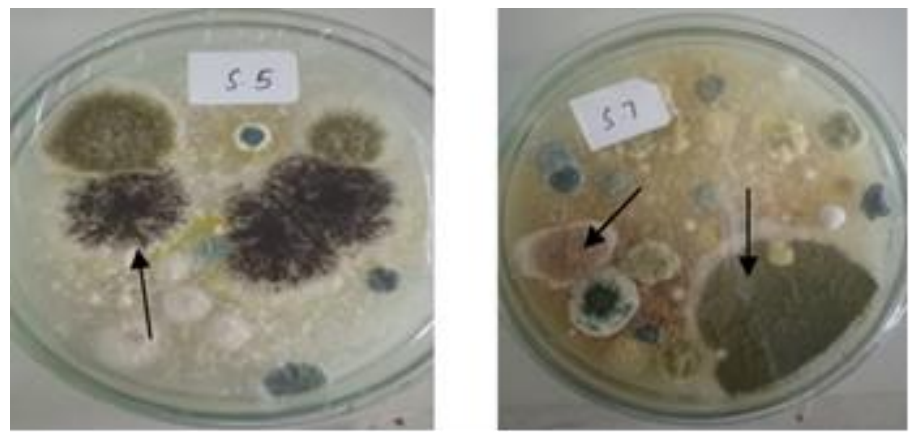


1) Aspergillus Niger, 2) Aspergillus flavus,

3) Aspergillus fumigatus, 4) Aspergillus tereeus
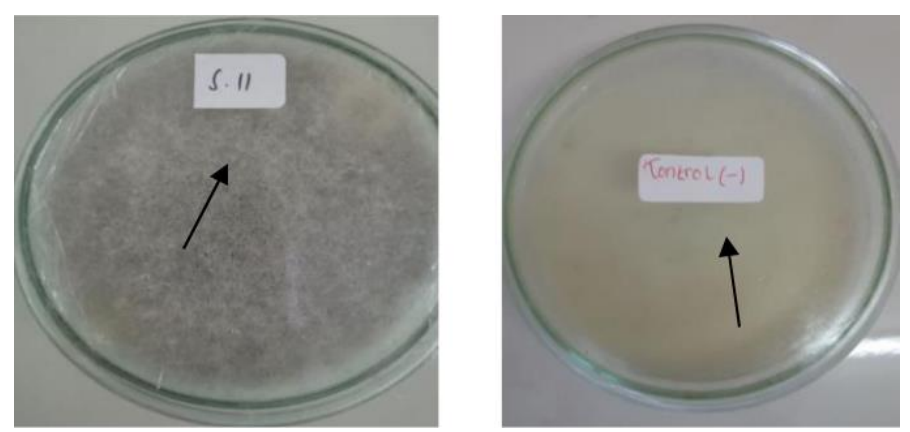

5) Negatif Aspergillus sp 6) Negative control

Figure 4. 1 Makroskipik Aspergillus sp

Source : Self Documentation, 2021

Table 4. 1 Macroscopic Observation

\begin{tabular}{|c|c|c|c|c|}
\hline \multirow[b]{2}{*}{ Hyphae Colour } & \multicolumn{2}{|c|}{ Colony } & \multirow[b]{2}{*}{ Eksudat } & \\
\hline & Edge & Texture & & Suspect \\
\hline & & & Drop & Species \\
\hline
\end{tabular}

\begin{tabular}{llll}
\hline 1. Black & White Cattony & Norgillus
\end{tabular}

Niger

\begin{tabular}{lllll}
\hline $\begin{array}{l}\text { Green } \\
\text { 2. yelowish }\end{array}$ & White & Velvety & No & Aspergillus \\
& & & & \\
& & & & Flavus \\
\hline 3. Dark green & White & Velvety & No & Aspergillus \\
& & & & Fumigatus \\
\hline 4. Light brown & White & Velvety & No & Aspergillus \\
& & & & Terreus
\end{tabular}


Identification of the fungus Aspergillus sp. in wheat flour that is sold openly was carried out macroscopically and microscopically including color, colony edges, texture, drop exudate, conidia and hyphae. The results of macroscopic observations can be seen in the table below.

After being observed macroscopically, then microscopic observations were made to identify what type of fungus Aspergillus sp. grows on wheat flour that is sold openly by looking at the characteristics. The results of microscopic observations can be seen in the table below.

Table 4. 2 Microscopic Observation

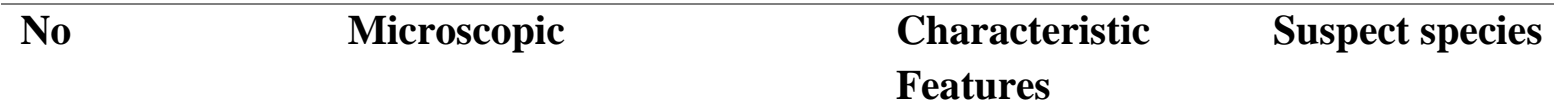

1

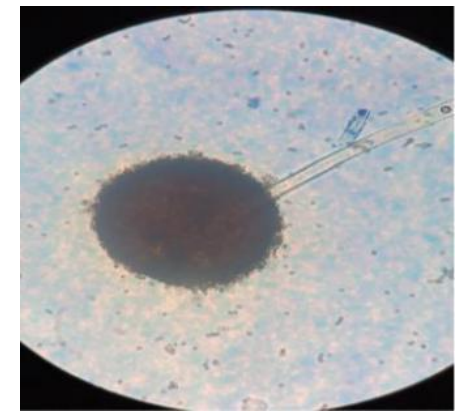

a. Conidia: dark brown until black, shaped round,

Aspergillus niger

hyaline smooth-

walled

b. Hyphae:

Transparent and not aspirated

(P:40X)
2

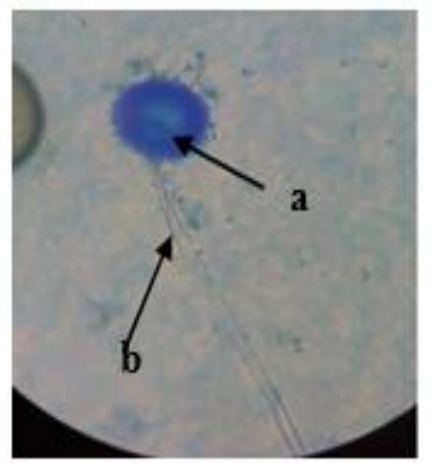

a. Conidia: blue colored, shaped round sized small, Aspergillus flavus hyaline insulated.

b.Hyphae:

Transparent, and not aspirated

(P:40X) 


IJMA: International Journal Mathla'ul Anwar of Halal Issues
Volume 1 Number 2: September 2021
e-ISSN: 2775-6157
p-ISSN: 2807-2952

Based on table 4.2, it is known that there are types of Aspergillus that grow in several samples, namely Aspergillus niger, Aspergillus flavus, Aspergillus fumigatus and Aspergillus terreus. Below are data from 30 samples of wheat flour which are sold openly in the Ciroyom market.

Table 4. 3 Result from 30 Samples

\begin{tabular}{cccccc}
\hline Sample & A.Niger & A.Flavus & A.Fumigatus & A.terreus & Keterangan \\
& & & & & \\
\hline 1 & - & + & - & - & Aspergillus $s p$ \\
& & & & & \\
\hline 2 & + & - & + & - & Aspergillus $s p$ \\
& & & & & \\
\hline 3 & - & - & - & - & -
\end{tabular}




\begin{tabular}{|c|c|c|c|c|c|}
\hline 4 & - & - & + & - & Aspergillus sp \\
\hline 5 & + & + & + & & Aspergillus sp \\
\hline 6 & - & + & + & - & Aspergillus sp \\
\hline 7 & - & + & + & + & Aspergillus sp \\
\hline 8 & - & + & + & - & Aspergillus sp \\
\hline
\end{tabular}

\begin{tabular}{llllll}
\hline 9 & - & - & - & - & - \\
& & & & & \\
\hline 10 & - & - & + & - & Aspergillus $s p$
\end{tabular}

\begin{tabular}{llllll}
\hline 11 & - & - & - & - & -
\end{tabular}

\begin{tabular}{llllllll}
\hline 12 & - & + & & + & & &
\end{tabular}

\begin{tabular}{|c|c|c|c|c|c|}
\hline 13 & - & - & - & - & - \\
\hline 14 & - & + & + & - & Aspergillus sp \\
\hline 15 & + & + & - & - & Aspergillus sp \\
\hline 16 & - & + & - & - & Aspergillus sp \\
\hline
\end{tabular}




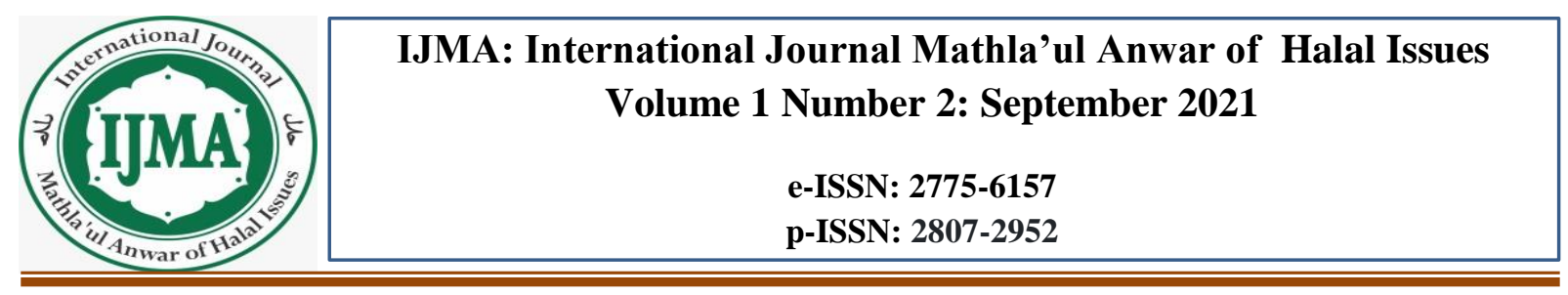

\begin{tabular}{lllllll}
\hline 17 & + & - & + & & & Aspergillus sp \\
\hline 18 & - & - & - & - & -
\end{tabular}

\begin{tabular}{llllll}
\hline 19 & - & - & - & - & - \\
& & & & & \\
\hline 20 & - & + & + & - & Aspergillus sp
\end{tabular}

\begin{tabular}{llllll}
\hline 21 & - & - & - & - & -
\end{tabular}

\begin{tabular}{lllllllllll}
\hline 22 & - & + & + & + & & - & Aspergillus sp
\end{tabular}

\begin{tabular}{lllllllllll}
\hline 23 & - & - & - & + & & + & & Aspergillus sp
\end{tabular}

\begin{tabular}{llllllllll}
\hline 24 & - & - & - & + & & & & & \\
\hline
\end{tabular}

\begin{tabular}{llllllllll}
\hline 25 & + & + & + & + & & & & &
\end{tabular}

\begin{tabular}{|c|c|c|c|c|c|}
\hline 26 & - & + & - & - & Aspergillus sp \\
\hline 27 & - & + & - & - & Aspergillus sp \\
\hline
\end{tabular}

\begin{tabular}{lllllll}
\hline 28 & - & - & - & - & -
\end{tabular}




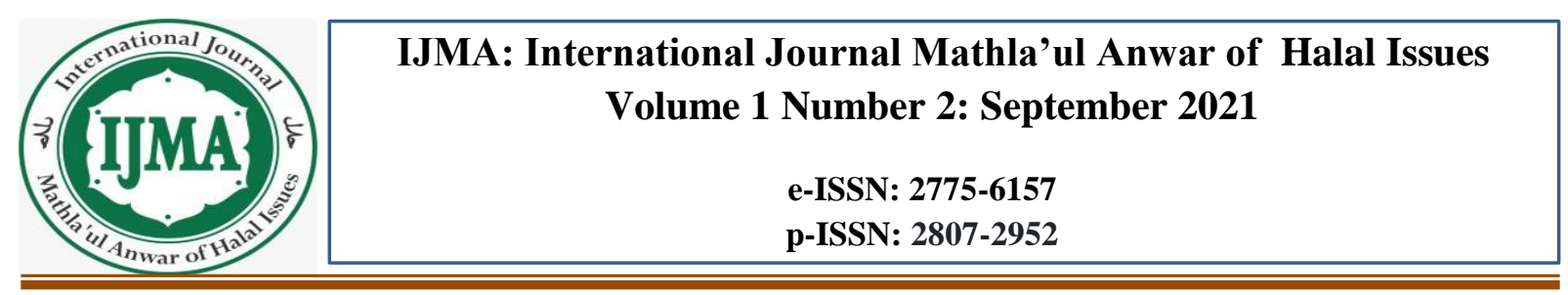

29

$+$

Aspergillus sp

30

$+$

Aspergillus sp

Negative

control

Viewed from table 4.3, 22 positive samples of Aspergillus niger, Aspergillus flavus, Aspergillus fumigatus, Aspergillus terreus were obtained. and 8 negative samples of Aspergillus sp. Then the percentage of fungi that grow and do not grow in the table below.

Table 4. 4 Percentage of Aspergillus sp

\begin{tabular}{llll}
\hline Identification Result & N & Amount & Presentase
\end{tabular}

\begin{tabular}{llll}
\hline Aspergillus niger & 30 & 5 & $16,7 \%$
\end{tabular}

\begin{tabular}{llll}
\hline Aspergillus flavus & 30 & 15 & $50 \%$
\end{tabular}

\begin{tabular}{llll}
\hline Aspergillus fumigatus & 30 & 15 & $50 \%$
\end{tabular}

\begin{tabular}{llll}
\hline Aspergillus terreus & 30 & 1 & $3,3 \%$
\end{tabular}

\begin{tabular}{llll}
\hline Negatif & 30 & 8 & $26,7 \%$
\end{tabular}

Explanation : $\mathrm{N}:$ Amount of wheat flour examined

Based on table 4.4 that half of them have Aspergillus flavus(50\%), Aspergillus fumigatus (50\%), a small proportion of Aspergillus niger (16.7\%), Aspergillus terreus (3.3\%) and almost half were negative (26.7\%) Aspergillus sp.

In this study, the sample used was wheat flour. Wheat flour is the main raw material used in the manufacture of various food products, such as bakery, noodles spaghetti, pizza, etc. Where the sampling is in accordance with the criteria, namely wheat flour which is sold 
openly and sold in the Ciroyom Market. The medium used for isolation is Sabouroud Dextrose Agar which is a selective medium for the growth of fungi and yeasts. This medium consists of 15 grams of agar, 40 grams of dextrose which is a fermented carbohydrate in high concentration as an energy source. There are also 5 grams of animal tissue enzymatic and 5 grams of casein enzymes, both of which provide amino acids and nitrogen compounds for the growth of fungi and yeasts. The $\mathrm{pH}$ contained is 5.6 acidic (Mutiawati, 2016). The media is first made, if the media is solid, the sample is isolated as much as 1 gram using the sowing method, then incubated for 3-5 days at $27^{\circ} \mathrm{C}$.

According to Gandjar (2006), there are several factors that can affect fungal growth, namely optimal temperature of $27^{\circ} \mathrm{C}$ but there are also fungi that can grow at $12-55^{\circ} \mathrm{C}$, for example Aspergillus fumigatus, the required $\mathrm{pH}$ is 5-6. Generally, fungi such as mucor or Rhizopus require 90\% humidity while for Penicillium, fusarium, and Aspergillus the humidity level is $80 \%$. In addition, the most needed factor for substrate fungi as a source of new nutrients is used after the fungus secretes enzymes and breaks down simple compounds.

After being incubated for 3-5 days, the media were observed macroscopically for color, colony edges, texture, and exudate drop, conidia and hyphae. After that, microscopic observations were carried out to ensure that Aspergillus sp., the staining used was LPCB (Lactophenol Cotton Blue). Lactate serves to clarify the background and sharpen the mushroom structure (Savitri, 2012).

The results obtained from the study of wheat flour which was sold openly in the Ciroyom market from 30 samples showed that almost half of them contained the fungus Aspergillus sp. The types of Aspergillus that have been identified macroscopically and microscopically are Aspergillus niger, Aspergillus flavus, Aspergillus fumigatus, and Aspergillus terreus. Aspergillus niger was obtained as much as $16.7 \%$ in wheat flour macroscopically has the characteristics of black colonies, the surface is like Cattony, there were no exudate droplets (in the form of liquid dots visible on the surface of the colony), there were no concentric circles, and there were no radial lines.

Microscopically, the conidia are dark brown to black, round in shape, large in size, hyaline with smooth walls, transparent hyphae. This fungus causes black fungus disease in onions, peanuts, grapes, certain vegetables and fruits (Refai, 2014). Aspergillus niger is useful for industry because it can produce galic acid, a phenolic compound that can be used in the food industry as an antioxidant and has a toxin in the form of ochratoxin. If Aspergillus niger is inhaled it will cause reactions such as allergic alveolitis and asthma (Handajani, 2006).

Aspegillus flavus found as much as $50 \%$ of this fungus often contaminates food can produce aflatoxins and is hepatotoxic and carcinogenic (Khasanah, 2013). Macroscopically, the colonies were yellowish green, cotton-like surface (Cottony), there were no exudate droplets (in the form of liquid dots visible on the colony surface), there were no concentric circles, and there were no radial lines. While microscopically the conidia heads were round, yellowish green, conidiophores were rough-walled, hyaline in color, and vesicles were round. 
Aspergillus fumigatus can produce helfolic acid which causes liver damage (Khasanah, 2013). The results obtained were 50\% which macroscopically had the characteristics of dark green colony color, like cotton (Cottony), there were no exudate droplets (in the form of liquid dots visible on the surface of the colony), there were no concentric circles, and there were no lines. radials. whereas macroscopically small oval conidia attached to the ends of one or two rows of strigmata that are regularly coiled on the tip surface of the conidiopore called vesicles.

Aspergillus terreus was found in a small percentage of $3.3 \%$ macroscopically having the characteristics of a light brown colony color, like cotton (Cottony), there were no exudate droplets (in the form of liquid dots visible on the surface of the colony), there were no concentric circles, and there were no lines. Radials by microscopic conidia are blue, fanshaped. conidiophores: hyaline and smooth-walled, hyphae transparent. The types of Aspergillus sp. were found in 30 samples of wheat flour which were sold daily.

\section{CONCLUSION}

From the research on the identification of the fungus Aspergillus sp. in wheat flour which is sold openly in the Ciroyom market, the results obtained were Aspergillus flavus, Aspergillus fumigatus, Aspergillus niger and Aspergillus terreus so we can conclude that the wheat flour that is sold openly is still a halal product but it is not mushroom-free products.

\section{REFERENCES}

1. Alvarez P, Mateos L, dkk. Polyclonal Aspergillus Fumigatus Infection In Captive Penguins. Veterinary Microbiology [serial online] 2010 [cited 2020 Oct 25]; 144(3):[444-449 screens].

2. Andoro Agus. Aspergillus sp Pada Sambal Kacang. [serial online] 2011 [cited 2020 Oct 22]; $1(1)$.

3. Anggelia Okthora. Penggunaan Metode Cawan Tuang Terhadap Uji Mikroba Pada Tepung Kelapa. Agritech of Science [serial online] 2020.

4. Arindi Amiranti, Fitria Dwiastuti. Nutrisi dan Media Pertumbuhan Jamur. [serial online] 21(2) 2017 [cited 2021 Juli 12].

5. Arishanti Wirawan. Pembuatan Media Nutrient Agar dan Sabouroud Dextrose Agar.[serial online] [cited 2021 Juli 19]. Available from: URL: https://atlmkes.wordpress.com.

6. BPOM. Keracunan Pangan. [Online]. 2017 [cited 2020 nov 22]; Available from; URL:https://mail.google.com/mail/u/0/\#inbox/15b8f01f69116262

7. BPOM. Sentra Informasi Keracunan Nasional. [Online]. 2016 [cited 2020 nov 22]; Available from; URL:http://ik.pom.go.id/v2016.

8. Gandjar. L. Sjamsuridjal, W \& Oeteri, A. Mikologi Dasar dan Terapan. Jakarta; 2006.

9. Gisslen, wayne. Professional Baking $6^{\text {th }}$ ed. Tangerang: Wiley:2017.

10. Hasanah, Uswatun. Mengenal Aspergillosis, Infeksi jamur genus Aspergillus. Jurnal Keluarga Sehat Sejahtera [Serial Online] 2017 Desember;15(2):76-86. 
11. Hidayatullah, Taufik. Identifikasi Jamur Rhizopuz sp Dan Aspergillus sp Pada Roti Bakar sebelum Dan Sesudah DiBakar Yang Dijual Di Alun-Alun Jombang[Serial Online] 2018 [cited Nov 2020 19].

12. Jawetz, Melnick, Adelberg. Mikrobologi Kedokteran. Jakarta 2010.

13. Jutono. Pedoman Praktikum Mikrobiologi Umum. Yogyakarta: Fakultas Pertanian UGM. 1980.

14. Marlina, Leni, Halimah, Susiwati. Revalensi Aspergillus fumigatus Pada Penjual Kacang Tanah dan jagung Kota Bengkulu. Jurnal kesehatan [serial online] 2014 Agustus;8(2):100204.

15. Mizana D. Identifikasi Pertumbuhan Jamur Aspergillus sp Pada Roti Tawar yang Dijual di Kota Padang Berdasarkan Suhu dan Lama Penyimpanan. JK [serial online] 2016 [cited 2020 Oct 15]; 5(2).

16. Mutiawati, V.K. 2016. Pemeriksaan Mikrobiologi pada Candida albicans. [serial online] 16 (1), 2016 [cited 2021 juli 23] Available from URL: http://eprints.poltekkesjogja.ac.id/1141/8/References.doc.pdf

17. Notoatmodjo. S. Metodologi Penelitian Kesehatan. Jakarta: Rineka Cipta. 2010 Noverita. (2009). Identifikasi Kapang dan Khamir Penyebab Penyakit Manusia Pada Sumber Air Minum Penduduk Pada Sungai Ciliwung dan Sumber Air Sekitarnya. [Serial Online] 2009 [cited nov 2020 20].

18. Nur Arie Syaifuddin. 2017. Identifikasi Jamur Aspergillus sp Pada Roti Tawar Berdasarkan Masa Sebelum Dan Sesudah Kadaluarsa [Serial Online]. 2017 [cited 2020 Nov 19].

19. Octavia, A., \& Wantini, S. Perbandingan pertumbuhan cendawan Aspergillus flavus pada media PDA (potato dextrose agar) dan media alternatif dari singkong. [serian online] 6(1), 2017 [cited 2021 juli 22].

20. Pratiwi, A. R., \&., Anjasari. Deteksi ergosterol sebagai indicator kontaminasi cendawan pada tepung terigu. J.inpan [serial online]2012 Feb-Mar [cited 2020 Oct 20]; 13(3):[255 screen].

21. Pujiati W, Ardiyanti L. Identifikasi Jamur Aspergillus sp Pada Tepung Teerigu yang Dijual Secara Terbuka Di Pasar Legi Jombang. [serial online] 2018 [cited 2020 Oct 15].

22. Rozi. Morfologi Jamur Aspergilus sp [Serial Online].2017 Nov 11[cited Nov 19]; Avaiable from URL: http://rozi-fpk.web.unair.ac.id/artikel_detail-212973PRAKTIKUM20MIKROBIOLOGIAspergillus\%20sp..htm

23. Savitri Rachmawati. Pewarnaan LPCB Pada Jamur. [serial online] 2012 [cited 2020 Oct 15]. Available from: URL: https://savitrirachmawati.wordpress.com

24. Separinta, Kepentingan pemerintah dalam mengeluarkan kebijakan pembatasan kuota impor tepung gandum. Fisip [serial online] 2017 Oct [cited 2020 oct 21]; (4)2:

Sukarminah, Sumantu dan Hanidah : Mikrobiologi Pangan. Jatinangor; 2008. Sunarsi A, Wahyuni S, dan Ratnaningsih W. Memanfaatkan Singkong MenjadTepung Mocaf untuk Pemberdayaan Sumberejo. [serial online] 2011 [cited 2020 Nov 15];

25. Syarbini, M. Referensi Komplet A-Z Bakery Fungsi Bahan, Proses Pembuatan Roti, Panduan Menjadi Bakepreneur 1th end. Tiga Serangkai Pustaka Mandiri. Solo. Wahyudi,

25. Utami T, Nugroho F, Usmiati S, Marwati S, dan Rahayu E. Penurunan Kadar Aflatoksin B1 Pada Sari Kedelai Oleh Sel Hidup Dan Mati Lactobacillus Acidophilus SNP-2. J.inpan [serial 


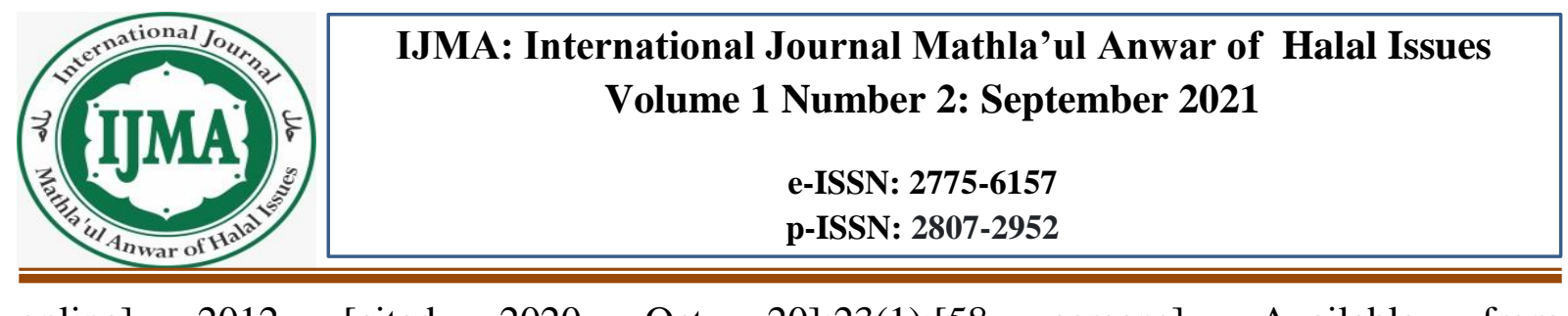

online] 2012 [cited 2020 Oct 20];23(1):[58 screens]. Available from URL:https://journal.ipb.ac.id/index.php/jtip/article/view/5295

26. WHO. First Ever Global Estimates Of Foodborne Diseases Find Children Under 5 Account For Almost One Third Of Deats. [Online]. 2015 [cited 2020nov 23]; Available from; URL:http://www.who.int/mediacentre/news/releases/2015/foodborne-sisease-estimates/en/ 